\title{
Seasonal incidence and effect of abiotic factors on population dynamics of major insect pests on brinjal crop
}

\author{
K. INDIRAKUMAR*, M. DEVI AND R. LOGANTHAN ${ }^{1}$ \\ Department of Agricultural Entomology, Tamil Nadu Agricultural University, COIMBATORE (T.N.) INDIA \\ ${ }^{1}$ Department of Agricultural Economics, Tamil Nadu Agricultural University, COIMBATORE (T.N.) INDIA
}

\section{ARITCLE INFO}

Received : 01.02 .2016

Revised : 16.02 .2016

Accepted : 01.03 .2016

\section{KEY WORDS :}

Abiotic factors, Leucinodes Orbonalis Guenee, Leaf hopper, White fly, Amrasca biguttula biguttula
*Corresponding author:

Email: indiraento@gmail.com

\begin{abstract}
Effect of abiotic factors on the seasonal incidence of major insect pests was observed on brinjal crop during Rabi 2009. The incidence of leaf hopper (Amrasca biguttula biguttula) was maximum during December, 52 nd Standard Week (SW) and minimum during March $\left(12^{\text {th }} \mathrm{SW}\right)$. The incidence of white fly (Bemisia tabaci) was maximum during January $\left(2^{\text {nd }} \mathrm{SW}\right)$ and lowest in March $\left(12^{\text {th }} \mathrm{SW}\right)$. Both these insects showed significant negative correlation with both maximum and minimum temperature and wind speed while a positive correlation was revealed with mean relative humidity and total rainfall. The incidence of shoot and fruit borer, Leucinodes orbonalis Guenee was observed during Nov. - Dec. with peak infestation during Feb. $\left(6^{\text {th }}\right.$ and $\left.7^{\text {th }} \mathrm{SW}\right)$. The per cent shoot damage was positively correlated with both maximum and minimum temperature, rainfall and wind speed while negatively correlated with mean relative humidity. While per cent fruit infestation revealed a non significant positive correlation with maximum and minimum temperature, rainfall and wind speed exhibited negative correlation with mean relative humidity. The statistically significant values indicated that occurrence of insect pests population was due to the prevailing ecological conditions. Thus the management of brinjal pest complex during Rabi sown brinjal should therefore be promoted and tailored from November onwards using an integrated approach.
\end{abstract}

How to view point the article : Indirakumar, K., Devi, M. and Loganthan, R. (2016). Seasonal incidence and effect of abiotic factors on population dynamics of major insect pests on brinjal crop Internat. J. Plant Protec., 9(1) : 142-145. 